\title{
Endoscopically Guided Resection of Brainstem Cavernous Malformations Through Miniature Corticotomies
}

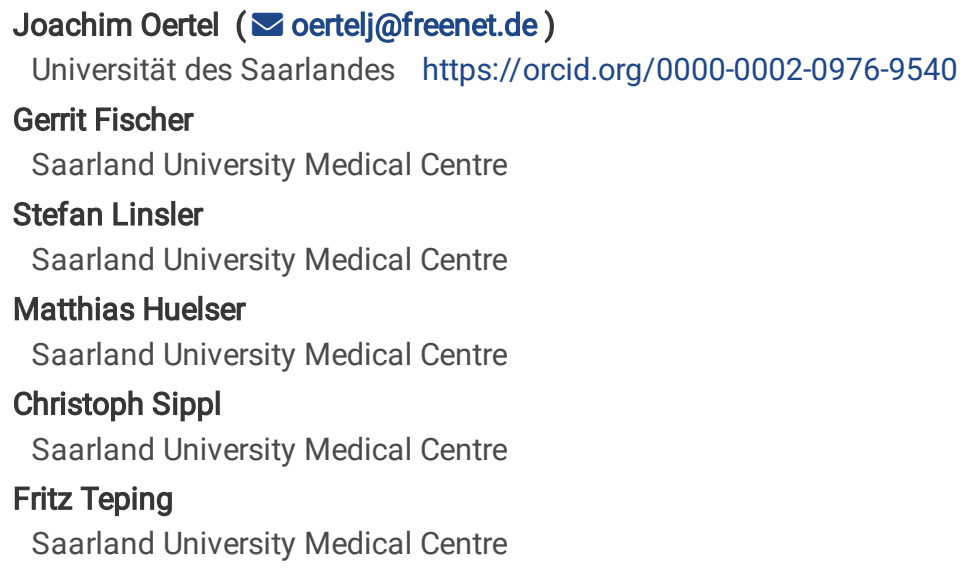

\section{Research Article}

Keywords: neuroendoscopy, endoscopic neurosurgery, brainstem, cavernoma, cavernous malformation

Posted Date: September 23rd, 2021

DOI: https://doi.org/10.21203/rs.3.rs-781241/v1

License: (c) (i) This work is licensed under a Creative Commons Attribution 4.0 International License. Read Full License 


\begin{abstract}
Objective:

Targeted surgical precision and minimally invasive techniques are of the utmost importance when it comes to resection of cavernous malformations involving the brainstem region. Minimization of the surgical corridor is desirable but should not compromise the extent of resection. This study provides detailed information on the role of endoscopic techniques in this challenging surgical task.
\end{abstract}

\title{
Methods:
}

A retrospective analysis of medical documentation, radiologic studies and detailed intraoperative video-documentation was performed for all consecutive patients, who underwent surgical resection of brainstem cavernous malformations between 2010 and 2020 at the authors' institution. A case-based volumetry of the corticotomy was performed in relation to the cavernoma's dimension.

\section{Results:}

A total of 20 procedures have been performed in 19 patients. Neuroendoscopy was implemented in all cases. Mean size of the lesion 5.4 $( \pm 5) \mathrm{mm}^{3}$. Average size of the brainstem corticotomy was $4.5 \times 3.7( \pm 1.0 \times 1.1) \mathrm{mm}$ with a median relation to the cavernoma's dimension of $9.99 \%(1.2 \%-31.39 \%)$. Endoscopic $360^{\circ}$ inspection of the resection cavity was feasible in all cases. There were no endoscopy related complications. Mean follow up was 27.8 (12-89) months. Gross-total resection was achieved in all but one cases (95\%). Sixteen procedures $(80 \%)$ resulted in an improved or stable medical condition. Eleven patients $(61.1 \%)$ showed further improvement 12 months after initial surgery.

\section{Conclusion:}

Experience provided, endoscopic techniques can be safely implemented in surgery for BSCM. Combination of neuroendoscopic visualization and neuronavigation might enable a targeted size of brainstem corticotomy. Endoscopy can be considered as a valuable additive tool to ensure gross total resection of BSCM.

\section{Introduction}

Intracranial cavernous malformations with their natural history and referring treatment modalities have been under investigation for a long time. However, there is still an ongoing debate on the best treatment modality of such lesions in highly vulnerable locations. Brainstem cavernous malformations (BSCM) represent $9-35 \%$ of all intracerebral cavernous malformations[1]. Due to re-bleeding rates of up to $34.7 \%$ once a bleeding occurred, BSCMs frequently come along with progressive, devastating neurological deficits[11, 36].

Gross total resection in this delicate area is considered the gold standard of therapy[4, 29]. Therefore, various approaches have been described[25, 42, 44]. Microsurgical techniques were applied in most of them. Meanwhile, neuroendoscopic techniques have proven to be a beneficial add-on in posterior fossa surgery $[5,16,22]$.

However, since the protection of adjacent structures, the definition of convenient entry points to the brainstem and the assurance of gross total resection are key factors for surgical success, neuroendoscopy may also contribute to favorable outcomes in this challenging pathology. It is the very purpose of this study to investigate potential benefits of neuroendoscopic techniques in different approaches to BSCM.

\section{Methods}

\section{General aspects and study population}

A retrospective analysis of a prospectively maintained database from 01/2010 to 01/2020 was performed. All patients who underwent surgical resection of BSCM were included. Data assessment consisted of medical documentation, perioperative radiographic imaging, intraoperative video documentation as well as follow-up examinations. Video documentation included separate high-definition records of the microsurgical and the endoscopic part, respectively.

\section{Surgery}

Indication for surgery was set if the patient showed red flag symptoms (progressive neurological deficits, deterioration of consciousness, or cardiovascular dysregulation due to brainstem compression), or if symptomatic re-bleeding was comprehensible. Risk stratification was performed using the Lawton-Garcia grading scale for BSCM[15]. A detailed, individual, three-dimensional, preoperative planning was performed based on MRI, DTI and fiber tracking data. 
All procedures have been carried out by the same senior surgeon (JO) with experience in endoscopic neurosurgery for more than 15 years. Main part of the surgery was performed under microscopic view (Pentero, CarlZeiss GmbH, Jena, Germany). Additional application of endoscopic techniques was carried out manually at different time points of the procedure. Maneuvering of the optics was free-handed. Endoscopic 2D-visualization was used only. In most cases, endoscopy was applied for visualization purposes. Preparation, coagulation or resection purely under endoscopic guidance was performed in selective situations (supplemental video). Endoscopic equipment was accessible at all time during surgery. It included a set of various rigid-rod lens Hopkins optics, as well as a high-definition visualization and recording unit (AIDA, Karl Storz Endoskopie, Tuttlingen, Germany). Intraoperative computed tomography (Siemens Healthcare GmbH, Erlangen, Germany) was available for MRI/CT-based neuronavigation with StealthAir System (Medtronic, Minneapolis, Minnesota, USA).

Surgeries covered the following approaches: Suboccipital midline $(n=14)$, retromastoidal-supracerebellar-infratentorial $(n=4)$, binostriltranssphenoidal-transclival[23]( $n=1)$ and right-frontal-transventricular $(n=1)$.

\section{Data analysis}

Medical data sets were evaluated regarding preoperative clinical status as well as medical condition after surgery and during follow up. Due to significant variations in follow up durations, medical condition and radiographic findings after 12 months were set as outcome parameters. Radiographic imaging was analyzed for defining the exact localization within the brainstem compartments preoperatively. Postoperative MRI controls after 6 and 12 months were reviewed independently in a blinded fashion. The extent of resection was evaluated 6 and 12 months after BSCM resection.

The intraoperative video material was analyzed in detail regarding visualization, endoscope-related morbidity, definition and volumetry of the BSCM compared to the size of the entry zone, illumination of the resection cavity as well as identification of residual cavernoma or bleedingspots. A synoptic video of endoscopically assisted BSCM resection was cut using Magix Software GmbH, Berlin, Germany.

The size of corticotomy was determined by a case-based analysis of the intraoperative video documentation in relation to the diameter of the implemented suction device (P.J. Dahlhausen \& Co. GmbH, Köln, Germany). Volumetric analysis of the BSCM was performed using the preoperative MRI imaging in axial, coronal and sagittal projections (SECTRA PACS, Sectra Medical Systems GmbH, Köln, Germany). All measurements were schematically illustrated using a 3D-graphic software (Tinkercard, Autodesk GmbH, München, Germany).

\section{Results}

\section{General}

A total of 20 procedures for BSCM have been performed in 19 patients (8 female, 11male) between January 2010 and January 2020.

Complete data sets were available for all patients. Mean age at date of surgery was $53.5( \pm 11.1)$ years. Average volume of the BSCM was 5.4 $( \pm 5) \mathrm{cm}^{3}$. An associated DVA could be identified and preserved in 4 cases (20\%). Multiple cavernous malformations in context of familiar disposition were seen in 2 patients (10\%). Acute bleeding of the BSCM was seen in 16 cases (80\%) prior to surgery. Four cases were admitted to the authors' department with progressive clinical deterioration but without signs of acute bleeding in preoperative MRI studies. Average BSCM classification after Lawton-Garcia grading system was Grade III (Grade I - Grade V). There were no high-risk classifications > Grade V. All but one cases underwent surgery within an acute $(0-3$ weeks; $n=12)$ or subacute $(3-8$ weeks; $n=3)$ timespan after BSCM hemorrhage. One patient experienced BSCM bleeding > 8 weeks prior to surgical resection. Mean operation time was 126.6 (61-209) minutes. A detailed characterization of the individual cases is listed in Table 1. 
Table 1

General information on the study population and clinical outcome

\begin{tabular}{|c|c|c|c|c|c|c|c|c|c|}
\hline case & $\operatorname{sex}$ & $\begin{array}{l}\text { age at } \\
\text { surgery } \\
\text { (years) }\end{array}$ & $\begin{array}{l}\text { location of } \\
\text { BSCM }\end{array}$ & $\begin{array}{l}\text { acute } \\
\text { bleeding }\end{array}$ & presurgical status & $\begin{array}{l}\text { status at } \\
\text { discharge } \\
\text { (mRS) }\end{array}$ & follow up & $\begin{array}{l}\text { radiologic } \\
\text { follow up }\end{array}$ & $\begin{array}{l}\text { duration } \\
\text { of follow } \\
\text { up } \\
\text { (months) }\end{array}$ \\
\hline 1 & $f$ & 13 & pons, left & yes & $\begin{array}{l}\text { sopor, palsy of CN } \\
\text { VI / VII (H\&B: 4) }\end{array}$ & $\begin{array}{l}\text { improved } \\
\text { (1) }\end{array}$ & $\begin{array}{l}\text { palsy of CN VII } \\
(\mathrm{H} \& \mathrm{~B}: 2)\end{array}$ & no residual & 89 \\
\hline 2 & $\mathrm{~m}$ & 60 & $\begin{array}{l}\text { dorsal medulla } \\
\text { oblongata, left }\end{array}$ & yes & $\begin{array}{l}\text { palsy of CN VII, } \\
\text { hemiparesis, FMD }\end{array}$ & $\begin{array}{l}\text { worsened } \\
\text { (6) }\end{array}$ & $\begin{array}{l}\text { death due to } \\
\text { severe pneumonia }\end{array}$ & - & - \\
\hline 3 & $\mathrm{~m}$ & 70 & pons, left & yes & $\begin{array}{l}\text { palsy of CN V / VI } \\
\text { / VII (H\&B: 4), } \\
\text { hemihypaesthesia }\end{array}$ & $\begin{array}{l}\text { improved } \\
\text { (1) }\end{array}$ & $\begin{array}{l}\text { residual palsy of } \\
\text { CN VII (H\&B: 2), } \\
\text { residual } \\
\text { hemihypaesthesia }\end{array}$ & no residual & 27 \\
\hline 4 & $\mathrm{~m}$ & 42 & $\begin{array}{l}\text { dorsal pons, } \\
\text { cerebellar } \\
\text { peduncle, 4th } \\
\text { ventricle }\end{array}$ & yes & vertigo & $\begin{array}{l}\text { improved } \\
(0)\end{array}$ & no deficit & no residual & 12 \\
\hline 5 & $f$ & 35 & medial pons & yes & $\begin{array}{l}\text { palsy of CN V / VII } \\
\text { / VIII }\end{array}$ & $\begin{array}{l}\text { improved } \\
\text { (1) }\end{array}$ & $\begin{array}{l}\text { residual palsy of } \\
\text { CN VII (H\&B: 4) }\end{array}$ & no residual & 62 \\
\hline 6 & $\mathrm{~m}$ & 59 & $\begin{array}{l}\text { dorsal medulla } \\
\text { oblongata }\end{array}$ & yes & $\begin{array}{l}\text { dysarthria, } \\
\text { hemihypaesthesia }\end{array}$ & $\begin{array}{l}\text { improved } \\
(2)\end{array}$ & mild dysphagia & no residual & 15 \\
\hline 7 & $f$ & 48 & central pons & yes & $\begin{array}{l}\text { bilateral palsy of } \\
\mathrm{CN} \mathrm{VI}\end{array}$ & stable (2) & $\begin{array}{l}\text { residual bilateral } \\
\text { palsy of CN VI }\end{array}$ & no residual & 12 \\
\hline 8 & $\mathrm{~m}$ & 63 & $\begin{array}{l}\text { dorsal } \\
\text { mesencephalon, } \\
\text { cerebellar } \\
\text { peduncle }\end{array}$ & yes & $\begin{array}{l}\text { vertigo, } \\
\text { hemihypaesthesia }\end{array}$ & $\begin{array}{l}\text { worsened } \\
\text { (3) }\end{array}$ & $\begin{array}{l}\text { residual palsy of } \\
\text { CN IV and } \\
\text { residual } \\
\text { hemihypaesthesia }\end{array}$ & no residual & 12 \\
\hline 9 & $\mathrm{~m}$ & 54 & central pons & yes & $\begin{array}{l}\text { hemihypaesthesia, } \\
\text { dysarthria, } \\
\text { dysphagia }\end{array}$ & stable (2) & $\begin{array}{l}\text { internuclear } \\
\text { ophtalmoplegia }\end{array}$ & no residual & 23 \\
\hline 10 & $f$ & 58 & dorsal pons & no & $\begin{array}{l}\text { severe headache, } \\
\text { paraesthesia }\end{array}$ & $\begin{array}{l}\text { worsened } \\
\text { (3) }\end{array}$ & $\begin{array}{l}\text { hemiparesis left } \\
(3 / 5), \text { palsy of CN } \\
\text { III left }\end{array}$ & no residual & 25 \\
\hline 11 & $\mathrm{~m}$ & 58 & $\begin{array}{l}\text { dorsal pons, } \\
\text { cerebellar } \\
\text { peduncle }\end{array}$ & yes & $\begin{array}{l}\text { severe headache, } \\
\text { FMD right hand, } \\
\text { vertigo }\end{array}$ & $\begin{array}{l}\text { improved } \\
(1)\end{array}$ & $\begin{array}{l}\text { residual mild FMD } \\
\text { right hand }\end{array}$ & $\begin{array}{l}\text { marginal } \\
\text { ischemia } \\
\text { within } \\
\text { cerebellar } \\
\text { peduncle; } \\
\text { no residual }\end{array}$ & 39 \\
\hline 12 & $\mathrm{~m}$ & 64 & $\begin{array}{l}\text { dorsal pons, } \\
\text { cerebellar } \\
\text { peduncle }\end{array}$ & no & $\begin{array}{l}\text { vertigo, severe } \\
\text { headache }\end{array}$ & $\begin{array}{l}\text { improved } \\
(1)\end{array}$ & no deficit & no residual & 51 \\
\hline 13 & $\mathrm{~m}$ & 56 & dorsal pons & yes & $\begin{array}{l}\text { hemihypaesthesia, } \\
\text { dysphagia }\end{array}$ & $\begin{array}{l}\text { worsened } \\
\text { (2) }\end{array}$ & palsy of CN III & no residual & 23 \\
\hline 14 & $f$ & 29 & ventral pons & yes & $\begin{array}{l}\text { palsy of CN VI /VII, } \\
\text { hemiparesis, FMD }\end{array}$ & $\begin{array}{l}\text { improved } \\
\text { (0) }\end{array}$ & no deficit & no residual & 12 \\
\hline 15 & $\mathrm{~m}$ & 46 & $\begin{array}{l}\text { mesencephalon, } \\
\text { right }\end{array}$ & no & $\begin{array}{l}\text { palsy of CN IV / V } \\
\text { / VI / VII (H\&B: } 3)\end{array}$ & $\begin{array}{l}\text { improved } \\
\text { (1) }\end{array}$ & $\begin{array}{l}\text { residual palsy of } \\
\text { CN IV }\end{array}$ & no residual & 15 \\
\hline 16 & $f$ & 50 & upper pons, left & no & $\begin{array}{l}\text { palsy of CN V, } \\
\text { hemiplegia, severe } \\
\text { dysarthria }\end{array}$ & $\begin{array}{l}\text { improved } \\
\text { (2) }\end{array}$ & $\begin{array}{l}\text { residual } \\
\text { hemiparesis }(4 / 5), \\
\text { slight dysarthria }\end{array}$ & no residual & 54 \\
\hline
\end{tabular}




\begin{tabular}{|c|c|c|c|c|c|c|c|c|c|}
\hline case & sex & $\begin{array}{l}\text { age at } \\
\text { surgery } \\
\text { (years) }\end{array}$ & $\begin{array}{l}\text { location of } \\
\text { BSCM }\end{array}$ & $\begin{array}{l}\text { acute } \\
\text { bleeding }\end{array}$ & presurgical status & $\begin{array}{l}\text { status at } \\
\text { discharge } \\
\text { (mRS) }\end{array}$ & follow up & $\begin{array}{l}\text { radiologic } \\
\text { follow up }\end{array}$ & $\begin{array}{l}\text { duration } \\
\text { of follow } \\
\text { up } \\
\text { (months) }\end{array}$ \\
\hline 17 & $f$ & 62 & $\begin{array}{l}\text { upper pons, } \\
\text { right }\end{array}$ & yes & $\begin{array}{l}\text { headache, } \\
\text { hemiparaesthesia }\end{array}$ & $\begin{array}{l}\text { improved } \\
(0)\end{array}$ & $\begin{array}{l}\text { second surgery } \\
\text { after } 6 \text { months } \\
\text { (case 20) }\end{array}$ & $\begin{array}{l}\text { residual } \\
\text { cavernoma } \\
\text { with re- } \\
\text { bleeding } \\
\text { after } 6 \\
\text { months }\end{array}$ & 13 \\
\hline 18 & $\mathrm{~m}$ & 69 & $\begin{array}{l}\text { upper pons, } \\
\text { right }\end{array}$ & yes & $\begin{array}{l}\text { right hemiparesis, } \\
\text { severe headache, } \\
\text { dysarthria }\end{array}$ & $\begin{array}{l}\text { improved } \\
(2)\end{array}$ & $\begin{array}{l}\text { residual mild } \\
\text { hemiparesis }(4 / 5)\end{array}$ & no residual & 16 \\
\hline 19 & $f$ & 73 & $\begin{array}{l}\text { ventral } \\
\text { mesencephalon }\end{array}$ & yes & $\begin{array}{l}\text { diplopia, palsy of } \\
\text { CN III, hemiparesis } \\
(3 / 5)\end{array}$ & stable (2) & $\begin{array}{l}\text { mild hemiparesis } \\
(4 / 5) \text {, residual } \\
\text { palsy of CN III }\end{array}$ & no residual & 16 \\
\hline 20 & $f$ & 62 & $\begin{array}{l}\text { upper pons, } \\
\text { right }\end{array}$ & yes & $\begin{array}{l}\text { palsy of CN III and } \\
\text { CN VII (H\&B: 4) }\end{array}$ & stable (1) & $\begin{array}{l}\text { residual palsy of } \\
\text { CN III and CN VII } \\
\text { (H\&B: 2) }\end{array}$ & no residual & 13 \\
\hline
\end{tabular}

Suboccipital midline approach (Fig. 1) was performed in 14 patients. Retromastoidal supracerebellar infratentorial approach (Fig. 2) was performed in 4 cases. Binostril transsphenoidal transclival approach (Fig. 3), as well as right frontal transventricular approach (Fig. 4) were performed in one case. All surgeries but two (transsphenoidal and transventricular approaches) were performed in semi-sitting position.

\section{Surgery}

Endoscopic techniques have been applied in all procedures. The binostril transsphenoidal transclival approach was performed pure endoscopically.

The favored entry point into the brainstem was defined under free-handed, bimanual endoscopic guidance and neuronavigation in all cases (Fig. 5). By combination of endoscopy and neuronavigation the size of corticotomy could be limited to an average of $4.5 \times 3.7( \pm 1.0 \times 1.1) \mathrm{mm}$. Median relation between the size of corticotomy and the maximum dimension of BSCM was $9.99 \%(1.2 \%-31.39 \%)$. A scaled, schematic illustration of the BSCM location within the brainstem, compared to the size of the entry point is shown for each case within Table 2.

Resection of the BSCM was performed under microscopic guidance with intermittent endoscopic inspection in all but the transsphenoidal case. Through the miniature corticotomy, pure microscopic inspection of the entire resection cavity was feasible and considered sufficient in 4 cases $(20 \%)$. In 16 cases $(80 \%)$, the resection cavity could not be inspected entirely with the microscope alone. By applying endoscopic visualization, extensive $360^{\circ}$ illumination of the resection cavity was feasible in all cases. A $0^{\circ}$ telescope with a range of up to $120^{\circ}$ wide view was applied primarily. Angled telescopes $\left(30^{\circ}, 60^{\circ}\right)$ were additionally needed in $16(80 \%)$ cases.

All surgeries were finished under the assumption of gross total resection. There was no endoscopy related contusion of surrounding brain tissue or eloquent structures. A detailed summary of endoscopy-related surgical outcome is shown in Table 2.

\section{Outcome and follow up}

An improvement of clinical symptoms immediately after surgery was documented in 12 cases (60\%). Four cases (20\%) remained clinically stable. Four surgeries $(60 \%)$ resulted in postoperative worsening compared to the preoperative status. Postoperative new cranial nerve palsies were seen in 4 cases (20\%). One patient suffered from terminal liver insufficiency and died 10 days after surgery due to severe pneumonia, unrelated to the BSCM surgery.

Postoperative imaging the day after surgery assured the absence of significant haemorrhage in all cases. One case (5\%) showed marginal, local postoperative ischemia within the cerebellar peduncle but without clinical correlation. One patient (5\%) showed residual cavernous malformation with re-bleeding six months after initial surgery (Table 1; case 17). Second surgery was performed in this patient and gross total resection could be achieved (Table 1; case 20).

Mean follow up was 27.8 (12-89) months. Clinical follow up after 12 months was accessible in 18/19 (94.7\%; one death) patients. None of those 18 patients showed clinical deterioration regarding initial postoperative symptoms. Eleven (61.1\%) patients showed an improvement of postoperative clinical status after 12 months. Seven patients (38.9\%) remained on the postoperative clinical status after 12 months. Three patients $(16.7 \%)$ were completely free of symptoms after 12 months.

\section{Discussion}




\section{General considerations}

BSCM is a rare condition. Scientific focus is set on different treatment modalities, the ideal time point of surgery or radiotherapy and surgical approaches[12, 15, 27, 30,36]. Indication for surgery is mainly given by a symptomatic lesion which is surgically accessible[40]. Al Mefty and Spetzler pointed out, that the definition of "surgically accessible" can be interpreted widely and that it rather depends on the institutions' experience in treatment of BSCMs[4]. Accordingly, it seems crucial to optimize surgical precision and effectiveness to the highest level possible. Implementation of neuroendoscopic techniques already improved surgical success in various pathologies of the posterior fossa, e.g., in intrameatal vestibular schwannoma resection[16, 19, 22, 24, 35]. Even comparably rare indications such as resection of optic pathway cavernous malformations have been treated successfully under endoscopic guidance[9, 39]. However, reports on endoscopic techniques in procedures for BSCM remain very limited to several case reports and small series (Table 3) $[3,10,17,18,23,26,32,33,38]$.

Table 3

List of literature reports on endoscopic techniques in surgery for BSCM

\begin{tabular}{|c|c|c|c|c|}
\hline publication & type of study & patients & endoscopy & approach \\
\hline $\begin{array}{l}\text { Sandalcioglu et al., } \\
2002^{30}\end{array}$ & $\begin{array}{l}\text { retrospective, single-center } \\
\text { series }\end{array}$ & 12 & $\begin{array}{l}\text { partly endoscopic } \\
\text { assisted }\end{array}$ & variable \\
\hline Sanborn et al., $2012^{29}$ & case report & 1 & fully endoscopic & transnasal, transclival \\
\hline Linsler \& Oertel, $2015^{14}$ & case report & 1 & fully endoscopic & transnasal, transclival \\
\hline Nayak et al., $2015^{23}$ & $\begin{array}{l}\text { retrospective, single-center } \\
\text { series }\end{array}$ & 4 & fully endoscopic & $\begin{array}{l}\text { transnasal, transclival; retrosigmoidal; } \\
\text { supracerebellar }\end{array}$ \\
\hline He et al., $2016^{24}$ & case report & 1 & fully endoscopic & transnasal, transclival \\
\hline $\begin{array}{l}\text { Gomez-Amador et al., } \\
2017^{27}\end{array}$ & case report & 1 & fully endoscopic & transnasal, transclival \\
\hline Erickson et al., 2018 28 & case report & 1 & fully endoscopic & transnasal, transclival \\
\hline Alikhani et al., $2019^{25}$ & case report & 1 & fully endoscopic & transnasal, transclival \\
\hline
\end{tabular}

\section{Surgery}

To preserve eloquent brain tissue and structures, a minimally-invasive approach and manipulation within the brainstem is crucial. The twopoint method, published by Brown et. al., aims towards limiting surgical corridors. In some cases of BSCM, when the direct approach crosses eloquent tissue, it even recommends an alternative, sometimes more demanding approach[7]. Moreover, extra- and intralesional bleeding has to be differed precisely to avoid unnecessary preparation[27]. In the presented cases the favourable entry point was defined under endoscopic view (Fig. 5). Thereby the subsequent corticotomy could be limited to an average of $4.5 \times 3.7( \pm 1.0 \times 1.1) \mathrm{mm}$. The minimal invasiveness is strengthened by the small median relation of $9.99 \%(1.2 \%-31.39 \%)$ between the surgical entry point and the maximum dimension of BSCM (figures within Table 2). Surgical invasiveness due to preparation on the brainstem surface could subsequently be limited effectively. Unfortunately, there is no systematic analysis on the size of corticotomy and its effect on surgical success or clinical outcome in microsurgical procedures available. Since endoscopically assisted resection of BSCM is the standard procedure for BSCM resection in the authors' department, neither an internal control group could be assessed. Accordingly, the presented results are lacking statistical proof of significance. However, the authors presume that a definition of convenient entry points under endoscopic and navigational guiding contributes to a less invasive surgical preparation.

In this study, endoscopes were applied free-handed and maneuvered manually at different timepoints of the procedure. While the authors are used to insert the optics purely under endoscopic visualization, modern microscopes enable a synergistic combination of both techniques in order to improve orientation and a safe handling. Such microscopic integration might advance getting familiar with endoscopic techniques in this specific indication. In the presented cases, only 2D-visualization was used. However, with an increasing frequency of endoscopically assisted or purely endoscopic procedures in neurosurgery, technological solutions for a stereoscopic view are demanded. In this context 3Dexoscoscopes turned out to be rather applicable in spinal procedures[8]. Possible advantages of 3D-HD-endoscopic visualization, as described for transsphenoidal pituitary surgery[37], remain elusive regarding BSCM resection. The authors used endoscopy mainly for additional inspection purposes. Only in few cases preparation, coagulation or resection is carried out under pure endoscopic guidance. Implementation of advanced endoscopic visualization technologies may form a basis for future BSCM resection purely under 3D-endoscopic guidance. 
The presented cases underline the possibility of a safe implementation of neuroendoscopy in various approaches to BSCMs. There were no intraoperative complications associated to the endoscope in this study. However, precautious maneuvering is essential, since the optics are inserted free-handed and guided manually. Manual handling, especially of angled endoscopes underlies a certain learning curve[34]. Whilst surgical results of endoscopic transsphenoidal procedures could be shown to significantly improve after 20-50 cases[20, 21], it seems obvious, that such numbers can hardly be achieved for BSCM. Thus, endoscopically assisted resection of BSCM should be reserved for extensively trained neuroendoscopists. The senior surgeon (JO) exhibits broad expertise regarding cranial and spinal endoscopic techniques for more than 15 years in daily practice. This may lead to the absence of endoscopy-related complications within the presented series and highlights the necessity of neuroendoscopic experience in this specific pathology.

Achievement of gross total resection remains the fundamental surgical goal. The risk of fatal re-bleeding due to remnant cavernoma cannot be emphasized enough $[6,45]$. Especially in deep seated lesions, microscopic insight into the resection cavity can be very limited[33]. This dilemma aggravates by minimizing the surgical entry point into the brainstem as shown in this series. In such cases, endoscopy can be of high value. As shown, endoscopic $360^{\circ}$ inspection of the resection cavity was possible in all cases, even through the smallest corticotomy of $2.8 \times 3.2 \mathrm{~mm}$. Due to the limited number of patients included and the absence of a statistical control group, a probabilistic analysis on detection rates with the endoscope cannot be provided. However, assurance of a gross total resection might be supported by additional endoscopic inspection and should be evaluated in further studies. Garcia et al. recently reported on a recurrence rate of $6.6 \%$ in his large series of 213 patients with BSCM in over 20 years. Blind spots and misinterpretation of the resection cavity's surface were considered important contributors defining between morbidity and cure[14]. We strongly believe, that the endoscope adds significant information for the neurosurgeon at this point. Especially considering the proposed right-angle-method[14], angled endoscopes might facilitate detailed inspection of potential blind spots. However, in the presented study, one patient (5\%) showed re-bleeding due to recurrence 6 months after initial resection. Hence, the endoscopic visualization should not be considered as guarantee for gross total resection. Despite the possibility of circumferential illumination of the resection cavity, undetected residual cavernoma tissue cannot be precluded. Yet, endoscopic inspection might reduce the risk of unidentified remnant BSCM, but the study design, with its limited case numbers and the absence of a microsurgical control group, does not allow a statistically convincing conclusion in this context and further prospective studies are needed.

\section{Clinical outcome}

Favorable clinical outcome after surgery for BSCM is reported in a majority of all cases. Improved or stable medical condition can be found in $61-91 \%[13,27,28,44]$. In the presented study $80 \%$ of the patients showed an improved, or at least stable, clinical status after surgery. Furthermore, $61.1 \%$ improved after another 12 months follow-up. Hence, the presented results seem very representative compared to previous studies.

Wu et al. reported a statistical trend of cavernous malformations involving cerebellar peduncle towards unfavorable short- and long-term outcomes[43]. In this study four patients showed BSCM reaching into cerebellar peduncle. Only one patient showed clinical deterioration after surgery, whilst the others had an excellent clinical outcome after 12 months. Without being able to strengthen it statistically the presented results cannot support this thesis.

Though overall clinical outcome appears to be favorable in the vast majority, intraoperative morbidity should not be despised. With a surgery related morbidity of $20 \%$, the presented study fits in between the reported morbidity rates of $10-37.3 \%[1,2,11,31,41]$. Compared to literature reports, implementation of endoscopic techniques for BSCM resection does not seem to increase the risk of surgery related morbidity. Taking into consideration that the surgeon's experience in neuroendoscopy is of high relevance in this context, an interindividual variety in morbidity rates must be assumed.

\section{Limitations}

The presented study has several important limitations. Despite the fact, that there is limited literature on endoscopic techniques in BSCM surgery available in particular, this study contains a limited number of patients. The retrospective character makes it susceptible to information and selection bias. Follow-up periods varied noticeably between the presented patients. Although almost all patients underwent clinical and radiological examination after 12 months, subsequent treatment in peripheral or distant hospitals impedes a consequent longterm follow-up in all patients. Major limitation is given by the absence of an internal control group for detailed statistical analysis. Since the endoscopically guided resection is the standard procedure for BSCM surgery within the authors' department, no internal data for such analysis was available. The presented conclusions must therefore be interpreted with restraint. It is the very purpose of this study to illuminate potential benefits of implementing neuroendoscopy in BSCM surgery. Hopefully, further institutions will be inspired to share their experience, enabling an intensified scientific discourse allowing a strong statistical evaluation.

\section{Conclusion}


With experience provided, endoscopic techniques can be safely implemented in surgical resection of BSCM. Combination of neuroendoscopic visualization and neuronavigation might enable a targeted size of brainstem corticotomy and an overall reduction of surgical invasiveness.

Endoscopic inspection can be considered as an additive tool to ensure gross total resection of BSCM. More extensive data is needed to enable statistical validation of these findings.

\section{Abbreviations}

BSCM = Brainstem Cavernous Malformation; CN = Cranial Nerve; H\&B = House and Brackman Score; $\mathrm{cm}=\mathrm{centimeter;} \mathrm{mm}=\mathrm{millimeter} ; \mathrm{FMD}=$ Fine Motor Dysfunction; mRS = modified Ranking Scale; EOR = Extend Of Resection; GTR = Gross Total Resection; STR = Subtotal Resection

\section{Declarations}

Disclosures:

Prof. Dr. med. Oertel is a consultant for Karl Storz GmbH, Tuttlingen, Germany. All authors declare that there is no personal or institutional profit regarding any device described within this article.

Funding: The presented study has not been supported financially.

Conflicts of interest: Prof. Dr. med. Oertel is a consultant for Karl Storz GmbH, Tuttlingen, Germany. All authors declare that there is no personal or institutional profit regarding any device described within this article.

Availability of data: All data acquired for this study is available for further inquiries.

Code availability: Not applicable.

Authors' contributions: Study conception and design: Joachim Oertel, Fritz Teping. Data acquisition: Fritz Teping, Matthias Hülser. Data processing: Fritz Teping, Christoph Sippl. Graphical illustration: Fritz Teping. Data analysis and interpretation: Joachim Oertel, Fritz Teping. Drafting of the manuscript: Joachim Oertel, Fritz Teping. Critical revision of the manuscript: All authors. Final approval of the submitted version of the manuscript: Fritz Teping. Study supervision: Joachim Oertel.

Ethics approval: This study was performed in accordance with the ethical standards of the Ethics Committee of Saarland.

Consent to participate: Not applicable.

Consent for publication: Not applicable.

\section{References}

1. Abla AA, Lekovic GP, Turner JD et al (2011) Advances in the treatment and outcome of brainstem cavernous malformation surgery: a single-center case series of 300 surgically treated patients. Neurosurgery 68:403-414. https://doi.org/10.1227/NEU.0b013e3181ff9cde discussion $414-405$.

2. Abla AA, Lekovic GP, Garrett $M$ et al (2010) Cavernous malformations of the brainstem presenting in childhood: surgical experience in 40 patients. Neurosurgery 67:1589-1598. https://doi.org/10.1227/NEU.0b013e3181f8d1b2 discussion 1598 - 1589.

3. Alikhani P, Sivakanthan S, Ashour R et al (2019) Endoscopic endonasal resection of a medullary cavernoma: a novel case. Br J Neurosurg 33:690-692. https://doi.org/10.1080/02688697.2017.1408777

4. Almefty KK, Spetzler RF (2015) Management of brainstem cavernous malformations. World Neurosurg 83:317-319. https://doi.org/10.1016/j.wneu.2014.03.019

5. Belykh E, Onaka NR, Zhao X et al (2018) Endoscopically Assisted Targeted Keyhole Retrosigmoid Approaches for Microvascular Decompression: Quantitative Anatomic Study. World Neurosurg 119:e1-e15. https://doi.org/10.1016/j.wneu.2018.04.218

6. Bertalanffy H, Gilsbach JM, Eggert HR et al (1991) Microsurgery of deep-seated cavernous angiomas: report of 26 cases. Acta Neurochir (Wien) 108:91-99. https://doi.org/10.1007/BF01418515

7. Brown A, Thompson B, Spetzler R (1996) The two-point method: evaluating brain stem lesions. BNI Q 12:20-24. https://doi.org/

8. Burkhardt BW, Csokonay A, Oertel JM (2020) 3D-exoscopic visualization using the VITOM-3D in cranial and spinal neurosurgery. What are the limitations? Clin Neurol Neurosurg 198:106101. https://doi.org/10.1016/j.clineuro.2020.106101 
9. Castelnuovo P, Arosio AD, Volpi L et al (2019) Endoscopic Transnasal Cryo-Assisted Removal of Orbital Cavernous Hemangiomas: Case Report and Technical Hints. World Neurosurg 126:66-71. https://doi.org/10.1016/j.wneu.2019.01.235

10. Erickson N, Siu A, Sherman JH et al (2018) Endoscopic Transnasal Transclival Approach to a Pontine Cavernoma with Associated Developmental Venous Anomaly. World Neurosurg 118:212-218. https://doi.org/10.1016/j.wneu.2018.07.084

11. Ferroli P, Sinisi M, Franzini A et al (2005) Brainstem cavernomas: long-term results of microsurgical resection in 52 patients. Neurosurgery 56:1203-1212; discussion 1212 - 1204. https://doi.org/

12. Frischer JM, Gatterbauer B, Holzer S et al (2014) Microsurgery and radiosurgery for brainstem cavernomas: effective and complementary treatment options. World Neurosurg 81:520-528. https://doi.org/10.1016/j.wneu.2014.01.004

13. Fritschi JA, Reulen HJ, Spetzler RF et al (1994) Cavernous malformations of the brain stem. A review of 139 cases. Acta Neurochir (Wien) 130:35-46. https://doi.org/10.1007/BF01405501

14. Garcia RM, Oh T, Cole TS et al (2020) Recurrent brainstem cavernous malformations following primary resection: blind spots, fine lines, and the right-angle method. J Neurosurg. doi:10.3171/2020.6.JNS2015551-12. https://doi.org/10.3171/2020.6.JNS201555

15. Garcia RM, Ivan ME, Lawton MT (2015) Brainstem cavernous malformations: surgical results in 104 patients and a proposed grading system to predict neurological outcomes. Neurosurgery 76:265-277. https://doi.org/10.1227/NEU.0000000000000602 discussion 277 268.

16. Goksu N, Yilmaz M, Bayramoglu I et al (2005) Evaluation of the results of endoscope-assisted acoustic neuroma surgery through posterior fossa approach. ORL J Otorhinolaryngol Relat Spec 67:87-91. https://doi.org/10.1159/000084623

17. Gomez-Amador JL, Ortega-Porcayo LA, Palacios-Ortiz IJ et al (2017) Endoscopic endonasal transclival resection of a ventral pontine cavernous malformation: technical case report. J Neurosurg 127:553-558. https://doi.org/10.3171/2016.8.JNS161137

18. He SM, Wang Y, Zhao TZ et al (2016) Endoscopic Endonasal Approach to Mesencephalic Cavernous Malformations. World Neurosurg 90:701 e707-701 e710. https://doi.org/10.1016/j.wneu.2016.02.064

19. King WA, Wackym PA (1999) Endoscope-assisted surgery for acoustic neuromas (vestibular schwannomas): early experience using the rigid Hopkins telescope. Neurosurgery 44:1095-1100. https://doi.org/10.1097/00006123-199905000-00084 discussion 1100 - 1092.

20. Kshettry VR, Do H, Elshazly K et al (2016) The learning curve in endoscopic endonasal resection of craniopharyngiomas. Neurosurg Focus 41:E9. https://doi.org/10.3171/2016.9.FOCUS16292

21. Leach P, Abou-Zeid AH, Kearney T et al (2010) Endoscopic transsphenoidal pituitary surgery: evidence of an operative learning curve. Neurosurgery 67:1205-1212. https://doi.org/10.1227/NEU.0b013e3181ef25c5

22. Li J, Zhong D, Lu D et al (2018) [Neuroendoscopy assisted microneurosurgery for posterior cranial fossa lesion]. Zhonghua Yi Xue Za Zhi 98:1311-1316. https://doi.org/10.3760/cma.j.issn.0376-2491.2018.17.006

23. Linsler S, Oertel J (2015) Endoscopic Endonasal Transclival Resection of a Brainstem Cavernoma: A Detailed Account of Our Technique and Comparison with the Literature. World Neurosurg 84:2064-2071. https://doi.org/10.1016/j.wneu.2015.08.029

24. Marchioni D, Carner M, Rubini A et al (2016) The Fully Endoscopic Acoustic Neuroma Surgery. Otolaryngol Clin North Am 49:1227-1236. https://doi.org/10.1016/j.otc.2016.05.014

25. Maurer AJ, Bonney PA, Strickland AE et al (2015) Brainstem cavernous malformations resected via miniature craniotomies: technique and approach selection. J Clin Neurosci 22:865-871. https://doi.org/10.1016/j.jocn.2014.10.028

26. Nayak NR, Thawani JP, Sanborn MR et al (2015) Endoscopic approaches to brainstem cavernous malformations: Case series and review of the literature. Surg Neurol Int 6:68. https://doi.org/10.4103/2152-7806.155807

27. Negoto T, Terachi S, Baba Y et al (2018) Symptomatic Brainstem Cavernoma of Elderly Patients: Timing and Strategy of Surgical Treatment. Two Case Reports and Review of the Literature. World Neurosurg 111:227-234. https://doi.org/10.1016/j.wneu.2017.12.111

28. Pandey P, Westbroek EM, Gooderham PA et al (2013) Cavernous malformation of brainstem, thalamus, and basal ganglia: a series of 176 patients. Neurosurgery 72:573-589. https://doi.org/10.1227/NEU.0b013e318283c9c2 discussion 588 - 579.

29. Petr O, Lanzino G (2015) Brainstem cavernous malformations. J Neurosurg Sci 59:271-282. https://doi.org/

30. Poorthuis MH, Klijn CJ, Algra A et al (2014) Treatment of cerebral cavernous malformations: a systematic review and meta-regression analysis. J Neurol Neurosurg Psychiatry 85:1319-1323. https://doi.org/10.1136/jnnp-2013-307349

31. Porter RW, Detwiler PW, Spetzler RF et al (1999) Cavernous malformations of the brainstem: experience with 100 patients. J Neurosurg 90:50-58. https://doi.org/10.3171/jns.1999.90.1.0050

32. Sanborn MR, Kramarz MJ, Storm PB et al (2012) Endoscopic, endonasal, transclival resection of a pontine cavernoma: case report. Neurosurgery 71:198-203. https://doi.org/10.1227/NEU.0b013e318259e323

33. Sandalcioglu IE, Wiedemayer H, Secer S et al (2002) Surgical removal of brain stem cavernous malformations: surgical indications, technical considerations, and results. J Neurol Neurosurg Psychiatry 72:351-355. https://doi.org/10.1136/jnnp.72.3.351

Page 9/15 
34. Schroeder HW, Oertel J, Gaab MR (2004) Incidence of complications in neuroendoscopic surgery. Childs Nerv Syst 20:878-883. https://doi.org/10.1007/s00381-004-0946-y

35. Setty P, D'Andrea KP, Stucken EZ et al (2015) Endoscopic Resection of Vestibular Schwannomas. J Neurol Surg B Skull Base 76:230-238. https://doi.org/10.1055/s-0034-1543974

36. Taslimi S, Modabbernia A, Amin-Hanjani S et al (2016) Natural history of cavernous malformation: Systematic review and meta-analysis of 25 studies. Neurology 86:1984-1991. https://doi.org/10.1212/WNL.0000000000002701

37. Uozumi Y, Taniguchi M, Nakai T et al (2020) Comparative Evaluation of 3-Dimensional High Definition and 2-Dimensional 4-K Ultra-High Definition Endoscopy Systems in Endonasal Skull Base Surgery. Oper Neurosurg (Hagerstown) 19:281-287. https://doi.org/10.1093/ons/opz426

38. Vaz-Guimaraes F, PA GA, Fernandez-Miranda JC et al (2016) Endoscopic endonasal skull base surgery for vascular lesions: a systematic review of the literature. J Neurosurg Sci 60:503-513. https://doi.org/

39. Venkataramana NK, Rao SA, Arun LN et al (2016) Cavernous malformation of the optic chiasm: Neuro-endoscopic removal. Asian J Neurosurg 11:68-69. https://doi.org/10.4103/1793-5482.145114

40. Walcott BP, Choudhri O, Lawton MT (2016) Brainstem cavernous malformations: Natural history versus surgical management. J Clin Neurosci 32:164-165. https://doi.org/10.1016/j.jocn.2016.03.021

41. Wang CC, Liu A, Zhang JT et al (2003) Surgical management of brain-stem cavernous malformations: report of 137 cases. Surg Neurol 59:444-454. https://doi.org/10.1016/s0090-3019(03)00187-3 discussion 454.

42. Wang Z, Qian C, Shi L et al (2015) Surgery Approaches to Brainstem Cavernous Malformations. J Craniofac Surg 26:e577-e580. https://doi.org/10.1097/SCS.0000000000002128

43. Wu H, Yu T, Wang S et al (2015) Surgical Treatment of Cerebellar Cavernous Malformations: A Single-Center Experience with 58 Cases. World Neurosurg 84:1103-1111. https://doi.org/10.1016/j.wneu.2015.05.062

44. Zhang S, Lin S, Hui X et al (2017) Surgical treatment of cavernous malformations involving medulla oblongata. J Clin Neurosci 37:63-68. https://doi.org/10.1016/j.jocn.2016.11.014

45. Ziyal IM, Sekhar LN, Salas E et al (1999) Surgical management of cavernous malformations of the brain stem. Br J Neurosurg 13:366375. https://doi.org/10.1080/02688699943466

\section{Tables}

Due to technical limitations, table 2 is only available as a download in the Supplemental Files section.

\section{Figures}




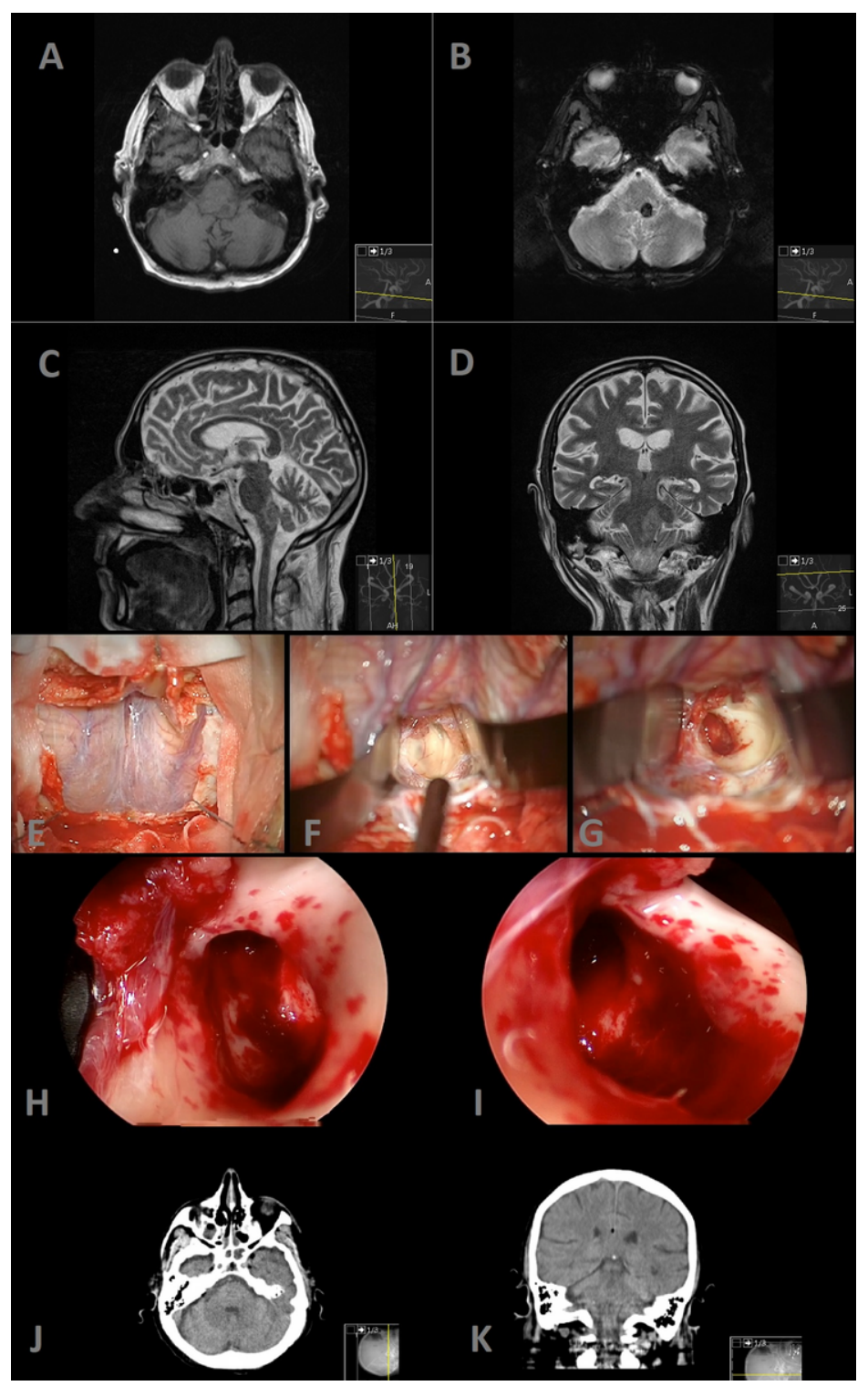

\section{Figure 1}

Illustrative case of a 59-year-old male patient with BSCM reaching pial surface at the dorsal medulla oblongata left. Preoperative MRI studies are shown in A-D. Surgical approach was a suboccipital midline craniotomy with telovelar access to the brainstem (E+F). After microsurgical resection $(G)$, the cavity is inspected carefully with angled endoscopes $(\mathrm{H}+\mathrm{I})$. Postoperative CT-scan showed no complications $(\mathrm{J}+\mathrm{K})$. 


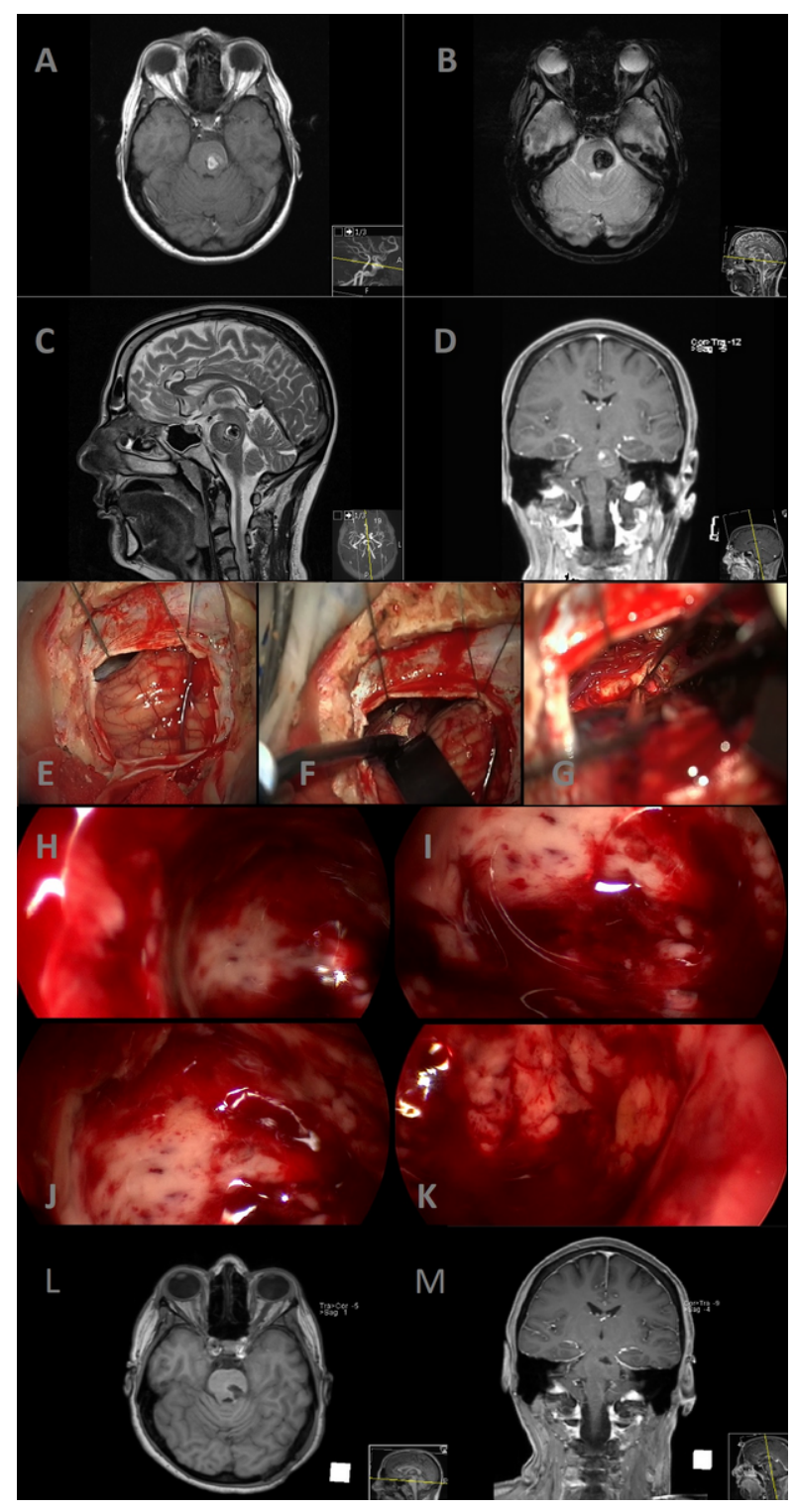

\section{Figure 2}

Illustrative case of a 46-year-old male patient suffering from BSCM located in the upper pons left. Preoperative MRI studies are shown in (A-D). A retromastoidal craniotomy is performed to gain access to the lesion under gentle retraction of the cerebellum (E+F). After corticotomy, the BSCM is resected under microscopic view. Limited visualization of the cavity by the microscope is shown in (G). Endoscopic $360^{\circ}$-illumination of the resection cavity is shown in H-K. Postoperative MRI showed no residual cavernoma $(L+M)$. 


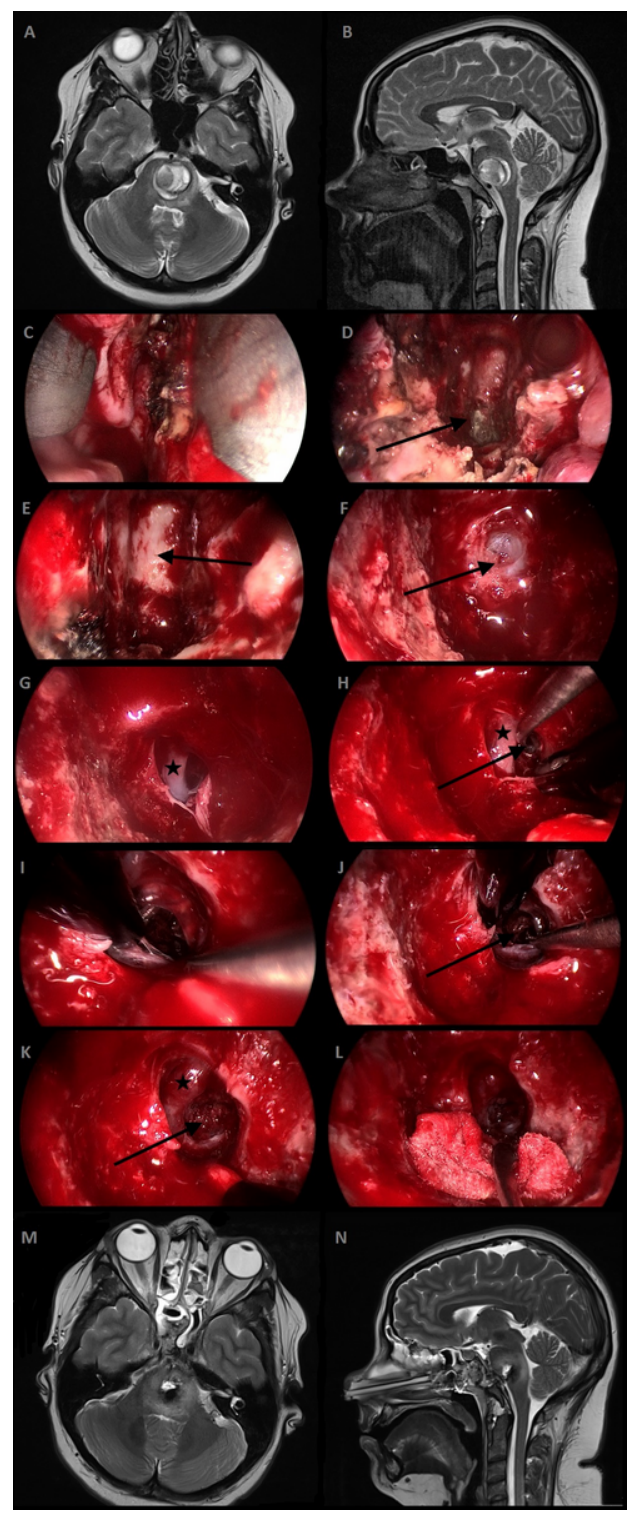

\section{Figure 3}

Illustrative case of a 29-year-old female Patient with BSCM reaching ventral surface of the pons. Preoperative MRI studies are shown in A+B. Transsphenoidal, transclival, pure endoscopic resection was performed (C-L). The sphenoid sinus was inspected (D; arrow) and the clivus (E; arrow) was resected by drilling. After opening of the dura mater ( $F$; arrow) basilar artery could be clearly identified (G; star). Corticotomy ( $\mathrm{H}$; arrow) was performed laterally to the basilar artery $(\mathrm{H}$; star) and the BSCM $(\mathrm{J}$; arrow) was resected consecutively. Inspection of the resection cavity (K; arrow) showed no residual cavernoma or bleeding. Postoperative MRI studies showed significant pressure relief and gross total resection $(\mathrm{M}+\mathrm{N})$. 


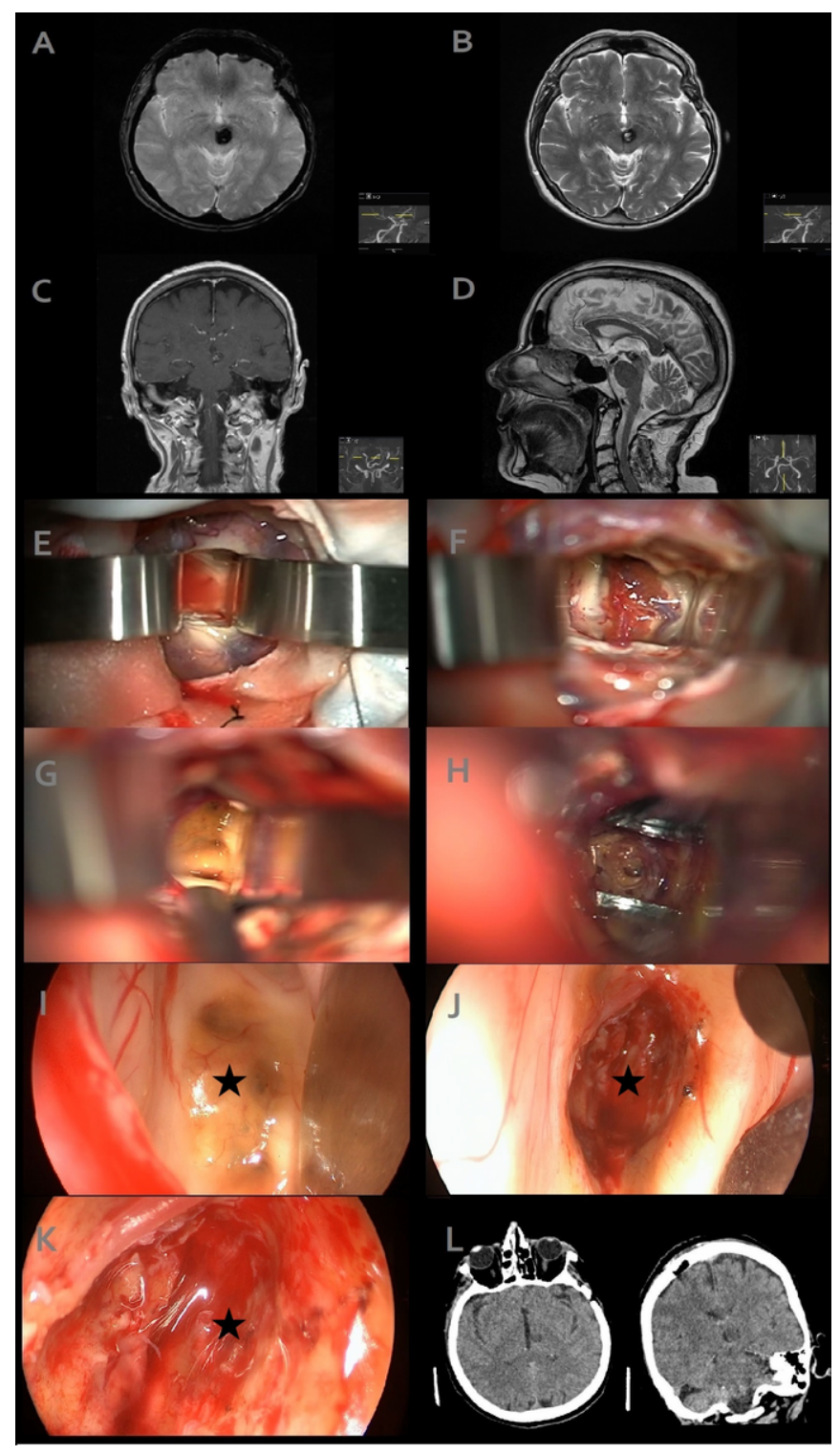

\section{Figure 4}

Illustrative case of a 73-year-old female patient suffering from BSCM located ventrally within the mesencephalon. Preoperative MRI studies are shown in A-D. A right frontal, transcortical approach to the lateral and third ventricle was performed to reach the entry point (E-G). The cavernoma was identified by endoscopic inspection ( $($; star) and resected afterwards $(\mathrm{H})$. Final inspection of the cavity with different angled endoscopes revealed no remnant cavernoma tissue, nor significant bleeding (J-K; star). Postoperative CT-scan showed no infarction nor bleeding (L). 


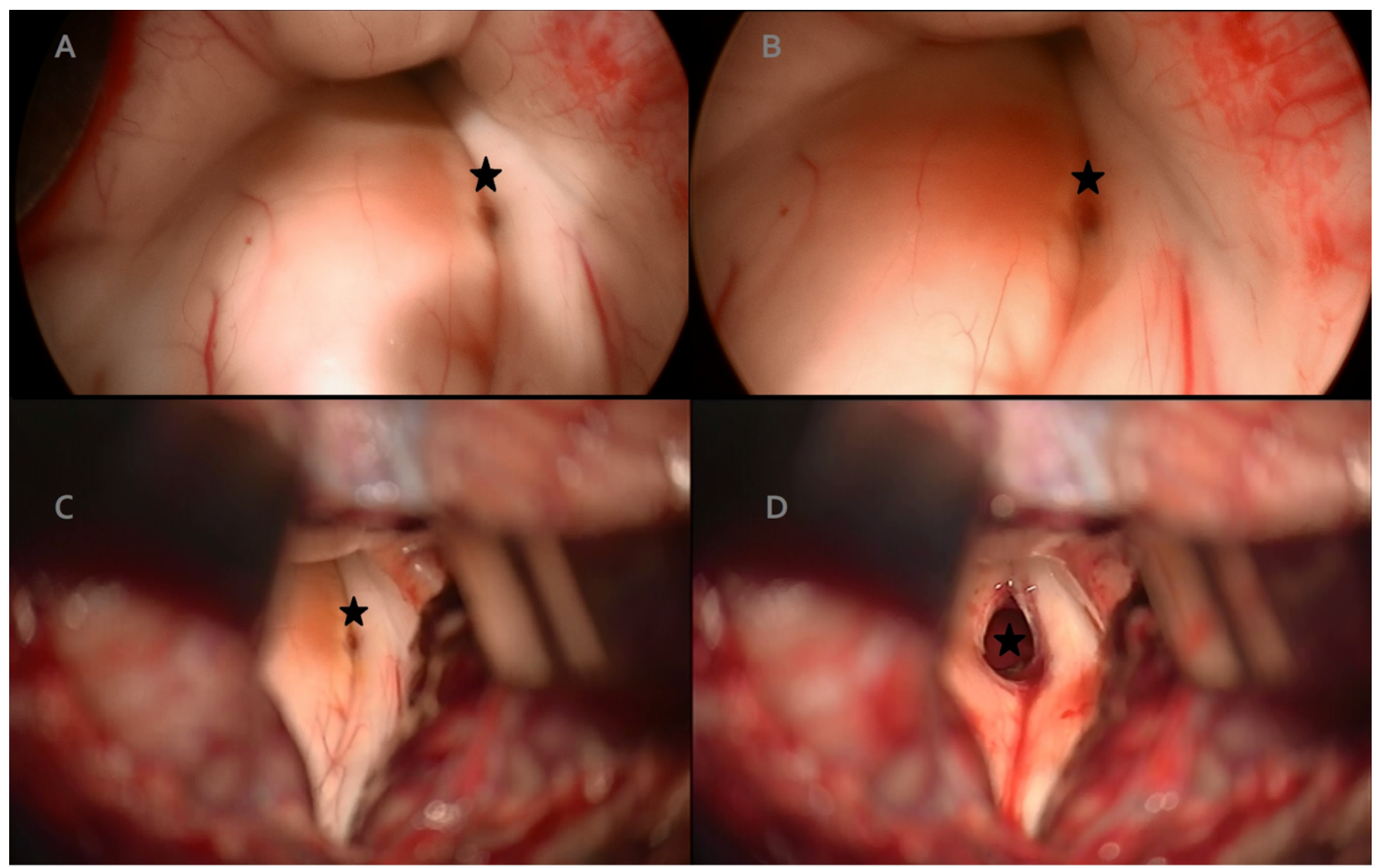

\section{Figure 5}

Definition of the entry point for corticotomy by the endoscope. The breakthrough of cavernoma tissue at the pial surface was inspected endoscopically (star, A+B). Minimal corticotomy was performed at the defined entry point (star, C+D).

\section{Supplementary Files}

This is a list of supplementary files associated with this preprint. Click to download.

- SupplementalvideoNR.mp4

- Table2.docx 